\title{
Western science severs ties with Russia
}

\section{Country's science renaissance threatened as NATO and NASA suspend links.}

\section{BY QUIRIN SCHIERMEIER}

cientific relations between Russia and

$\mathrm{S}$ the West have reached their lowest ebb since the cold war, after Russia annexed Ukraine's Crimean peninsula. The North Atlantic Treaty Organization (NATO) and NASA both cut ties with Russia last week.

On 1 April, NATO suspended all civilian and military cooperation with Russia. This affects scientific collaboration under the organization's Science for Peace and Security Programme, which underpins counterterrorism and disaster-relief work, including work on technology that can detect hidden bombs at crowded public-transport locations. NATO is looking for other partners to continue these projects.

And on 2 April, the US government suspended all contact between NASA and Russian space agencies and government representatives — including visits, meetings and even e-mails. Only activities involving the International Space Station are permitted to continue. The space station has both Russian and US crewmembers on board, and has relied on Russian Soyuz craft for transport since the United States retired its shuttle fleet in 2011.

It is unclear how other space-science collaborations will be affected. Igor Mitrofanov of the

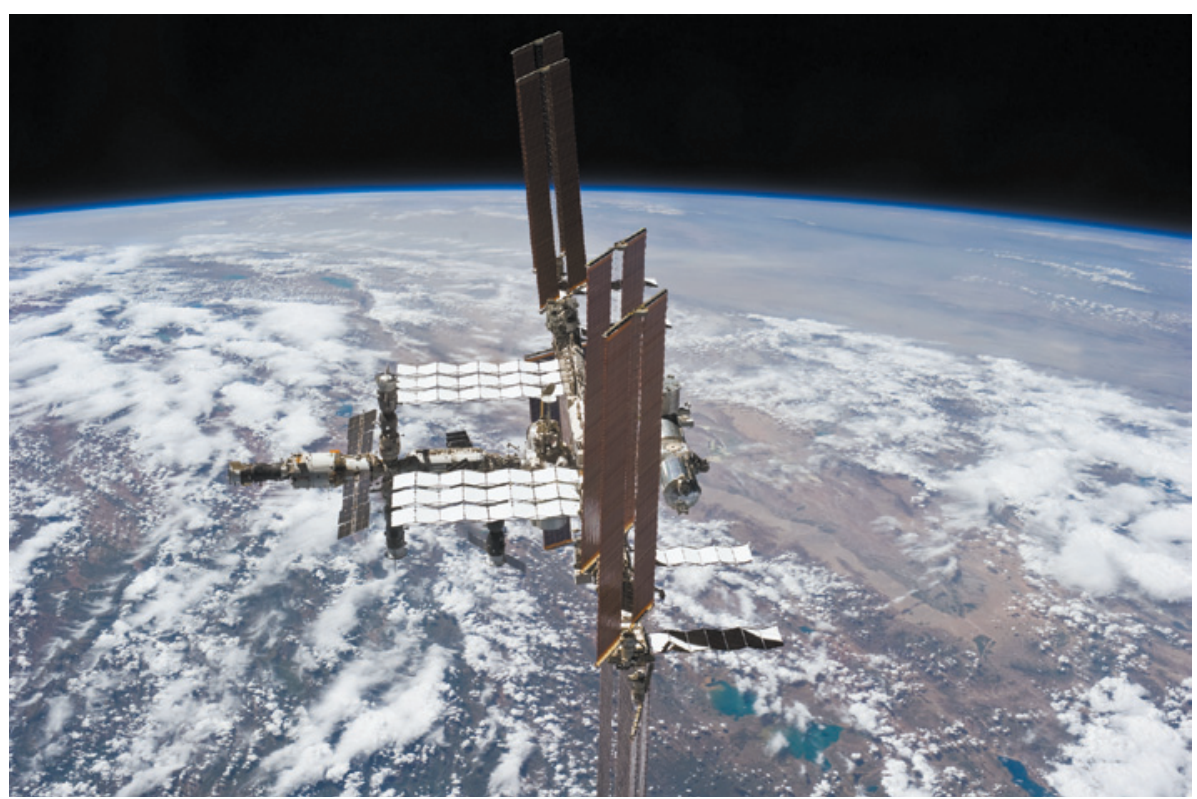

The International Space Station is exempt from NASA's restrictions on formal dealings with Russia.
Space Research Institute in Moscow, who led work on a neutron-detector device on NASA's Mars Curiosity rover, says that he will not comment on the issue until NASA has notified him of the situation.

The United States and the European Union (EU) have also imposed sanctions against several high-ranking Russian government officials. The US list includes former science minister Andrei Fursenko, who acts as a personal science adviser to Russian President Vladimir Putin.

The United States, the EU and Russia have embarked on diplomatic efforts to defuse the situation in Crimea following a crisis meeting in Paris on 30 March between US secretary of state John Kerry and Russian foreign minister Sergey Lavrov. If those efforts fail, Russia's increasing isolation could become a serious long-term problem for Russian and international science, says Harley Balzer, who specializes in international affairs and Russian politics at Georgetown University in Washington DC.

"If Russia were to push one inch further into Ukraine, cutbacks on all sorts of academic exchange programmes and scientific collaborations will inevitably follow," says Balzer. Affected schemes could include the US Fulbright Program, which funds scholarly exchanges with several countries, including Russia.
Further sanctions, Balzer adds, would thwart Russia's efforts to strengthen its research and education systems and to attract foreign talent. In his 2012 election campaign, Putin promised to create several 'world-class' universities by 2020 , and to substantially raise science spending - it currently stands at a mere $1.3 \%$ of gross domestic product. "Putin is killing the chance to make up lost ground," says Balzer.

The symbol of Russia's science aspirations is the Skolkovo Institute of Science and Technology (Skoltech), an English-language research university being created on the outskirts of Moscow in partnership with the Massachusetts Institute of Technology (MIT) in Cambridge.

MIT is developing curricula and research programmes and providing administrative support to Skoltech. It is also running the international calls for proposals for Skolkovo's 15 planned research centres of excellence; 6 centres already exist and 4 more are to be created this year. The terms of MIT's contract with Skoltech are confidential, but sources say that Russia is paying the US institute at least US $\$ 300$ million (see Nature 500, 262-264; 2013). Balzer predicts that MIT will come under "enormous pressure" to shut down the collaboration should the Crimea crisis escalate.

Edward Crawley, an MIT engineer and the president of Skoltech, says that MIT and Russian officials wish to continue the partnership, and that plans for the four new centres are moving ahead. "Conveying the idea of Skoltech takes on additional significance in these times of strained relations," says Crawley. "When the seas between two countries are stormy, it is the role of scientists and educators to put ballast to the bottom of the ship."

Attracting scientists from abroad is crucial for Russia's scientific renaissance, says Irina Dezhina, a science-policy analyst at the Institute of World Economy and International Relations in Moscow, who heads a research group at Skoltech. A series of collaborative events has been planned to run throughout 2014 for the EU-Russian Year of Science. What happens now depends on the West, she says.

People might think twice about going to a country that violates international law, warns Oleg Kharkhordin, rector of Russia’s European University at St Petersburg. "But," he adds, "it should really be the interest of both sides to foster free scientific exchange." - SEE EDITORIALP.149 